\title{
The preparation of the Approved Lists of Bacterial Names
}

To celebrate the 25th anniversary of the publication of the Approved Lists of Bacterial Names in 1980, the surviving scientific editor Peter Sneath reflects on the conception, preparation and publication of this seminal document in the nomenclature of not just prokaryotes but all organisms.

The Approved Lists of Bacterial Names (Skerman et al., 1980) had its inception at a special meeting of the Judicial Commission in 1968, which was called to consider how to revise the International Code of

Bacteriological Nomenclature and to set a new starting date for bacterial names. There were about 30000 names in the literature, and it was clear that very few could be definitely associated with known species of bacteria. The exceptions were mostly pathogens that caused well-known diseases. A new starting date and starting document were therefore needed. This was the brainchild of the late Victor B. D. Skerman of the University of Queensland, who has the major credit. Other suggestions were made at this meeting, and I myself thought it would be sufficient to conserve a selection of well-established names, but I was soon convinced of Skerman's view. The late Stephen P. Lapage was also a strong supporter.

The existing starting point for names of bacteria was at that time the Species Plantarum of Linnaeus, 1753. The reform of bacterial nomenclature consisted of registering all new names in the International Journal of Systematic Bacteriology (IJSB) (now the International Journal of Systematic and Evolutionary Microbiology, IJSEM) from 1 January 1976 and then gathering these, together with well-founded old names, into the new starting document, the Approved Lists of 1 January 1980. From this date, all names not on the Lists lost their standing in nomenclature (though old names can be revived with certain safeguards). Thereafter new names had either to be published in the IJSB or, if published elsewhere, had to be announced in Validation Lists of the journal.
Many of these actions involved revision of the International Code of Nomenclature of Bacteria (Lapage et al., 1975, 1992), but this contribution focuses on the preparation of the Approved Lists. Further detail can be found in the prefaces to the Code and in a paper of a nomenclature conference (Sneath, 1986).

The idea of a new starting date was not new. Many years before, Samuel T. Cowan (1905-1976; see Sneath, 1977) had suggested that names should start around 1900, when modern culture methods had developed, and Skerman (1949) had also made similar proposals. But Robert E. Buchanan (1883-1973), who drafted the first Bacteriological Code (and to whom we are also indebted for his emphasis on type strains, which experience has shown are indispensable for maintaining stability), had such reverence for the past that he was unable to accept changes of this kind.

The preparation of the Lists was in two stages. An ad hoc committee was set up, comprising at various times V. B. D. Skerman, S. P. Lapage, H. P. R. Seeliger, J. G. Holt, L. G. Wayne and myself, which consulted widely and prepared and published a draft (Ad Hoc Committee of the Judicial Commission of the ICSB, 1976). The committee consulted the taxonomic subcommittees of the International Committee on Systematic Bacteriology (ICSB) where possible. For other organisms, much effort was made to find specialists on those groups. This very considerable correspondence was largely carried out by Skerman. I was responsible for suggesting the basic document to work from, and compiling names from this. This was the 8th edition of Bergey's Manual of
Determinative Bacteriology (Buchanan \& Gibbons, 1974), because it covered all bacteria, contained good descriptions and usually listed type strains. It was felt that this volume contained most of the secure information on names of bacteria. Not all names were accepted, but it provided a welcome framework on which to build. I also covered names above genus level.

Stephen Lapage of the National Collection of Type Cultures had considerable input to the Lists, though his main contribution was to completely revise the earlier Code, reduce it to essentials and put it into a more logical order (an achievement that has been underestimated). But this interacted with the policy of choosing acceptable names. He had many productive meetings with me in London or in a nearby tavern in Leicester.

Between 1976 and 1980 drafts were collated with responses from many workers. Considerable editorial work was provided by Vicki McGowan of the University of Queensland. Names from 1976 were gathered in, and the final document was published in the IJSB on 1 January 1980. From then, bacteriologists need only to consult the Approved Lists, the IJSB/IJSEM and any cumulative lists prepared there from (e.g. Moore \& Moore, 1989).

The entries in the Approved Lists contained four items: the name, the author citation, a reference to a published description and the nomenclatural type. The last was the type strain for species, the type species for genus and the type genus for higher ranks. For uncultivable forms the description had to represent the type. The Approved Lists contained about 2300 names, of which about 1800 were names of species and 300 names of genera, and there were 125 higher names. Relatively few acceptable names were inadvertently missed (see below). The Approved Lists were not updated, though a corrected version was later published (Skerman et al., 1989). The number of bacterial names has now grown to about 10000 . 
Most subcommittees were very cooperative. That on streptomycetes insisted on retaining about 400 names of species of Streptomyces and Streptoverticillium, many of which were of questionable status. Fortunately it did recommend type strains, so that future revision of these genera could be readily achieved. In contrast, the subcommittee on streptococci was reluctant to recommend any type strains on the grounds that they were unnecessary, but paradoxically it was keen to list reference strains for serological varieties. The ad hoc committee had to take a few arbitrary decisions, but the mechanism to allow old names to be revived later was a great help in gaining cooperation. A few hundred acceptable names were indeed revived in the next few years. No cyanobacteria were listed because so few had been cultured and generic limits were then so uncertain.

Higher names in bacteriology had never been consistent. Up to the rank of order they should be formed from the name of the type genus, e.g. family Pseudomonadaceae from genus Pseudomonas. Some early names were not, e.g. family Thiorhodaceae, though there is no genus Thiorhoda. Those not formed from a genus name were therefore omitted from the Approved Lists as being contrary to the Rules. Almost all bacteriologists accepted this with good grace and used names that were properly formed, e.g. Chromatiaceae from Chromatium for Thiorhodaceae.

The exception was the family name Enterobacteriaceae, which is not from the type genus Escherichia. An editorial footnote was added at a late stage in the text of the Lists. This stated that the name had been challenged and was sub judice. This was not quite correct: it was the omission of the name that was challenged. Proposals were made later to regularize this by amending the name to Enterobacteraceae (from Enterobacter) or to Escherichiaceae, and the matter was taken to the Judicial Commission, which declined to replace it by the properly formed name

Escherichiaceae (Wayne, 1984), unwisely in my view. The form of the footnote may have implied that Enterobacteriaceae was omitted by oversight: it was not. I decided after consulting Lapage that an improperly formed name could not be included, and that view was accepted at the time of compilation. It could be revived if wished. However, the ad hoc committee agreed at the start on a policy: in preparing such a complex document there were bound to be errors and disagreements that could not be solved in the time available; these would have to be left for later treatment. So members acquiesced in the inclusion of the name in the later revised edition of the Approved Lists (Skerman et al., 1989). But was the name on the Approved Lists of 1980 ? It was certainly printed on that document. The episode is not a very good example of collegiate behaviour.

This pretty kettle-of-fish illustrates a short-sighted decision which satisfied the convenience of contemporary workers at the price of burdening future students with an exception they have to remember. The distinguished medical bacteriologist W. $\mathrm{H}$. Ewing told the committee that it would win in the end. It is likely that this will finally happen, as moves are made to unify the codes across biology. Botanists are now replacing irregular names. Thus the family Cruciferae is now the Brassicaceae, the cabbage family, from Brassica, the cabbage. The case is an example of Cowan's adage that bacteriologists will tell you they are not interested in names - until you tamper with one of theirs.

The device of reviving old names in their original sense was very helpful as noted above, because it permitted obvious omissions to be corrected. It is, of course, not possible to forbid authors from using an old and forgotten name in a sense different from the original, otherwise workers would have to search the many thousands of literature items to avoid clashes. But in practice this has not proved serious. The plant pathologists made a major contribution by publishing a list of names of plant pathogens that were of doubtful status (Dye et al., 1980). Most are varieties adapted to particular host plants, i.e. pathovars. This nomenclature was taken from the use by botanists of cultivar as an abbreviation for cultivated variety, and extended in the Code to similar terms for other kinds of variety, e.g. chemovar, phagovar. The plant pathologists made recommendations against using these names again, and this policy has worked well. They had no difficulty in employing pathovar names for purposes of plant quarantine. In contrast, medical bacteriologists are slow to adopt serovar for serotype; one reason given is the problem of quarantine.

A few minor problems may be mentioned. Nomenclature is determined by taxonomy, not the reverse, so if a bacterium is placed in one genus by one worker and in another genus by another worker, it may be correctly named under two genera. Both names are right depending on which taxonomy is deemed correct. There were few cases where this occurred in the Approved Lists, mainly in the genera Beneckea and Vibrio. Fortunately, Russian bacteriologists did not insist on listing species of streptomycetes also under the genus Actinomyces as had been their practice earlier. There were also problems associated with the ranks of subgenera and subspecies, because such names cause a major increase in the complexity of the Rules. In the event few were listed, and there has been no complaint on this.

In retrospect, one is impressed by the excellent cooperation of the bacteriological community on a challenging endeavour. If imitation is the height of flattery, bacteriologists can feel content at current moves toward registering names in botany and zoology, and at unifying the various Codes of Nomenclature (Greuter et al., 1996). But principally the Approved Lists are a tribute to Vic Skerman, who despite disabling deafness steered with skill a difficult project to a highly successful conclusion. His brusque manner hid a generous heart. The last time I met him he said with glee 'We started something!'

\section{P. H. A. Sneath}

Department of Infection, Immunity and Inflammation, University of Leicester, Leicester LE1 9HN, UK

Correspondence: P. H. A. Sneath (phas1@le.ac.uk)

Ad Hoc Committee of the Judicial Commission of the ICSB (1976). First draft. Approved Lists of Bacterial Names. Int J Syst Bacteriol 26, 563-599.

Buchanan, R. E. \& Gibbons, N. R. (editors) (1974). Bergey's Manual of Determinative Bacteriology, 8th edn. Baltimore: Williams \& Wilkins. 
Dye, D. W., Bradbury, J. F., Goto, M., Hayward, A. C., Lelliott, R. A. \& Schroth, M. N. (1980). Standards for naming pathovars of phytopathogenic bacteria and a list of pathovar names and pathotype strains. Rev Plant Pathol 59, 153-168.

Greuter, W., Hawksworth, J., McNeill, J. \& 7 other editors (1996). Draft BioCode: the prospective international rules for the scientific names of organisms. Taxon 45, 349-372.

Lapage, S. P., Sneath, P. H. A., Lessel, E. F., Skerman, V. B. D., Seeliger, H. P. R. \& Clark, W. A. (editors) (1975). International Code of Nomenclature of Bacteria. Washington, DC: American Society for Microbiology.

Lapage, S. P., Sneath, P. H. A., Lessel, E. F., Skerman, V. B. D., Seeliger, H. P. R. \& Clark,
W. A. (editors) (1992). International Code of Nomenclature of Bacteria (1990 Revision). Washington, DC: American Society for Microbiology.

Moore, W. E. C. \& Moore, L. V. H. (1989). Index of the Bacterial and Yeast Nomenclatural Changes published in the International Journal of Systematic Bacteriology since the 1980 Approved Lists of Bacterial Names (1 January 1980 to 1 January 1989). Washington, DC: American Society for Microbiology.

Skerman, V. B. D. (1949). A mechanical key for the generic identification of bacteria. Bacteriol Rev 13, 175-188.

Skerman, V. B. D., McGowan, V. \& Sneath, P. H. A. (editors) (1980). Approved lists of bacterial names. Int J Syst Bacteriol 30, 225-420.
Skerman, V. B. D., McGowan, V. \& Sneath, P. H. A. (editors) (1989). Approved Lists of Bacterial Names (Amended Edition). Washington, DC: American Society for Microbiology.

Sneath, P. H. A. (1977). Obituary. Samuel Tertius Cowan, 1905-1976. J Gen Microbiol 103, $1-7$.

Sneath, P. H. A. (1986). Nomenclature of bacteria. In Biological Nomenclature Today, pp. 36-48. Edited by W. D. L. Ride \& T. Younès. Oxford: IRL Press.

Wayne, L. G. (1984). Actions of the Judicial Commission of the International Committee on Systematic Bacteriology on Requests for Opinions published in 1982. Int J Syst Bacteriol 34, 272-273. 